\title{
Root Coverage in Miller Classes I and II associated with Subepithelial Connective Tissue Graft: A comparative Clinical Trial of Two Techniques
}

\author{
${ }^{1}$ Vitor J Spada, ${ }^{2}$ Patricia O Nassar, ${ }^{3}$ Nahana Cardoso, ${ }^{4}$ Khadidjia MB Caldato, ${ }^{5}$ Jordana H Pandini \\ ${ }^{6}$ Deisy M Randon, ${ }^{7}$ Carlos A Nassar
}

\begin{abstract}
Introduction: Gingival recession is characterized by apical positioning of the gingival side in relation to the cementoenamel junction. Thus, this study aimed at evaluating the effectiveness of two surgical techniques for root coverage in patients with gingival recession of Miller class I or II.
\end{abstract}

Materials and methods: A total of 13 patients were selected, from the age group of 20 to 50 years, with bilateral gingival recession Miller class I or II, totaling 34 recessions. When the basic periodontal treatment was accomplished, every recession was included in one of both selected groups according to the surgical technique: Control group-Subepithelial connective tissue graft associated with coronally positioned flap technique and test group-Subepithelial connective tissue graft associated with the modified envelope technique. Patients were evaluated for 180 days, and the periodontal parameters were analyzed in 0,90 , and 180 days.

Results: The results showed that both surgeries were effective since they kept probe depths with periodontal health and clinical attachment gain $(p<0.05)$ in both groups, up from 90 days. The reduction was kept for 180 days, mainly for the control group that showed a clinical attachment gain that was still statistically significant at 180 days $(p<0.05)$. Regarding the root coverage, the control group showed a $90.2 \%$ of coverage while the test group showed $89.5 \%$.

${ }^{1}$ Department of Periodontology, Unipar Energy Systems Private Limited, Cascavel, Parana, Federal Republic of Brazil Department of Dentistry, West Paraná State University, Cascavel Parana, Federal Republic of Brazil

${ }^{2,7}$ Department of Periodontology, Júlio de Mesquita Filho State University, Cascavel, Parana, Federal Republic of Brazil Department of Periodontology, West Paraná State University Cascavel, Parana, Federal Republic of Brazil; Department of Biosciences and Health and Dentistry, West Paraná State University, Cascavel, Parana, Federal Republic of Brazil

3-5Department of Periodontology, School of Dentistry, West Paraná State University, Cascavel Parana, Federal Republic of Brazil

${ }^{6}$ Dentistry Auxiliar, Nurse Technique, Cascavel, Parana, Federal Republic of Brazil

Corresponding Author: Carlos A Nassar, Department of Periodontology, Júlio de Mesquita Filho State University, Cascavel Parana, Federal Republic of Brazil; Department of Periodontology West Paraná State University, Cascavel, Parana, Federal Republic of Brazil; Department of Biosciences and Health and Dentistry West Paraná State University, Cascavel, Parana, Federal Republic of Brazil, Phone: +554591013369, e-mail: canassar@yahoo.com
Conclusion: Thus, it can be concluded that both techniques, after 180 days, were effective for the health of periodontal tissues; however, a greater emphasis can be observed on the subepithelial connective tissue graft-associated coronally positioned flap technique because this technique demonstrated a greater significant gain in the clinical attachment level.

Clinical significance: The subepithelial connective tissue graft is used for gaining the clinical attachment level in the root coverage of patients with gingival recession Miller classes I and II.

Keywords: Gingival recession, Root coverage, Subepithelial connective tissue graft.

How to cite this article: Spada VJ, Nassar PO, Cardoso N, Caldato KMB, Pandini JH, Randon DM, Nassar CA. Root Coverage in Miller Classes I and II associated with Subepithelial Connective Tissue Graft: A comparative Clinical Trial of Two Techniques. World J Dent 2017;8(4):248-254.

\section{Source of support: Nil}

Conflict of interest: None

\section{INTRODUCTION}

Gingival recession is characterized by apical positioning of the gingival side in relation to the cementoenamel junction (CEJ). It is a common problem in patients with good standard of oral hygiene, both in maxilla and mandible, which can either be unit or multiple. ${ }^{1}$

Inadequate oral hygiene, inability or difficulty of a patient in removing plaque, folds, and fibrous formations near the gingival side along with some predisposing factors, such as thin gingival tissue (thin periodontal phenotype), prominent root surface, misplaced tooth, and bone dehiscence may contribute to their formation. ${ }^{2,3}$

To correct gingival recession, several techniques have been developed. A few among them are the coronally positioned flap technique associated with masticatory mucosal graft, initially described by Bernimoulin et $\mathrm{al}^{4}$ and modified by Liu and Solt. ${ }^{5}$ The main goal of surgical therapies is the complete covering of the root surface to obtain compatible depth soundings with periodontal health along with a chromatic integration and root coverage texture so that there is a great interaction among the adjacent periodontal tissues. ${ }^{6,7}$

The coronally positioned flap technique is a procedure that shows high significance in the complete root coverage that can be observed in some parts where there 
is no loss of papillae. ${ }^{6}$ Besides coronally positioned flap technique, there are some other techniques that were developed, one among them is by Langer and Langer. ${ }^{8}$ In this technique, the graft is placed in a subepithelial position on the exposed root surface, covered by a receiver epithelium, which moves the flap coronally to cover the graft. This also increases its protection and maximizes nutrition, once it is provided by both periosteum and flap surface on the graft. ${ }^{9}$

Another alternative technique of root coverage is placing the connective tissue graft within an "envelope", i.e., already prepared; ${ }^{10}$ however, in 1994, Allen ${ }^{11}$ modified this technique and included repositioning gingival margin in the coronal direction by fine suture. The recent literature demonstrated that the successful rates in the root coverage of Miller classes I and $\mathrm{II}^{12}$ with these techniques and under ideal conditions ${ }^{13}$ varied between 50 and $97.3 \%$ in the mean root coverage and it also varied between 7.7 and $91.6 \%$ for complete root coverage. ${ }^{14}$

Therefore, this study aimed at evaluating the effectiveness of two surgical techniques for root coverage in patients with Miller class I or II gingival recession.

\section{MATERIALS AND METHODS}

This research concerns the applied nature of explanatory character and its design was a randomized clinical trial. The project was approved by the Research and Ethics Committee in Human Beings at Unioeste, document was registered as no. 714,964. It was carried out at the clinics of the dentistry course, Campus of Unioeste in Cascavel, and a private dentistry clinic. A total of 67 patients were examined, and 16 of them were selected according to the inclusion criteria. There were three dropouts during the whole study: One because of disease in the family and another because of pregnancy, and the last one reported that the first surgery was very traumatic.

Regarding the analysis of sample size calculation, the patients' number was defined based on previous analyses, through a test power of $80 \%$ and 0.05 alpha level. These data were also based on previous studies of researchers' groups. ${ }^{15}$ The final sample size was 13 patients, in the age of 20 to 50 years, and with bilateral gingival recession Miller class I or II, totaling 34 recessions, with 17 recessions in each group. They were diagnosed with gingival recession, Miller classes I and II in more than one area of the dental jaw.

The inclusion criteria in the sample were patients of both gender (males and females), whose recession varied from 2 to $5 \mathrm{~mm}$ height (it was measured from the CEJ to the upper apical part of gingival recession) and between 2 and $4 \mathrm{~mm}$ width (it was measured the furthest area between both sides of the gingival tissue that surrounds recession). The bleeding index was $\leq 5 \%$ and carious free.
The exclusion criteria were any positive history for antibiotic therapy in the past 6 months, the use of antiinflammatory drugs or steroids in the past 3 months before the study was conducted, and any systemic problem that contraindicated surgical procedure. The medical record of each patient was obtained through anamnesis; all participants underwent clinical examination, and then, a basic periodontal treatment was carried out. The initial clinical/periodontal examination was carried out by a single trained individual, who used a Williams number 23 periodontal probe for determining plaque index, ${ }^{16}$ gingival index, ${ }^{17}$ probing depth, clinical attachment level, gingival level (recession), height of keratinized tissue, and dental sensibility (modified index of the US Public Health Service). ${ }^{18}$

Thereafter, each recession was randomly allocated by raffle in one of both selected groups, according to the treatments proposed in Table 1 . All patients received a basic periodontal treatment before the surgery, and, when necessary, a manual instrumentation was performed with periodontal curettes of Gracey 5/6, 7/8, 11/12, and 13/14 (Hu-Friedy, Chicago, Illinois, USA). All patients were instructed to follow the modified bass technique of toothbrushing and received maintenance care. After the 180 day trial period, all patients were included in a periodontal maintenance program.

\section{Coronally Positioned Flap Technique}

The studied area received an infiltrative terminal anesthesia with mepivacaine $2 \%$ and epinephrine 1:100,000 (DFL, Rio de Janeiro, RJ, Brazil). An intrasulcular incision was carried out with a 15 c Solidor ${ }^{\circledR}$ blade (Suzhou Kyuan Medical Apparatus Co. Ltd., Suzhou City Beiqiao Town, China) (Fig. 1) as well as horizontal incisions on papilla base at CEJ level at mesial and distal parts so that the epithelial papilla could be removed.

Initially, the flap was displaced in its whole thickness until the mucogingival line. The flap was then displaced into partial thickness so that a flap with a good flexibility

Table 1: Distribution of 34 recessions according to the treatment proposed

\begin{tabular}{|c|c|c|c|}
\hline $\begin{array}{l}\text { Control group } \\
\text { ( } \mathrm{n}=17 \text { recessions): } \\
\text { Subepithelial } \\
\text { connective tissue } \\
\text { graft by the coronally } \\
\text { positioned flap } \\
\text { technique }\end{array}$ & $\begin{array}{l}\text { Basic } \\
\text { periodontal } \\
\text { treatment }\end{array}$ & $\begin{array}{l}\text { Surgical } \\
\text { technique }\end{array}$ & $\begin{array}{l}\text { Maintenance } \\
\text { therapy }\end{array}$ \\
\hline $\begin{array}{l}\text { Test group } \\
\text { ( } n=17 \text { recessions): } \\
\text { Subepithelial } \\
\text { connective tissue } \\
\text { graft by the modified } \\
\text { envelope technique }\end{array}$ & $\begin{array}{l}\text { Basic } \\
\text { periodontal } \\
\text { treatment }\end{array}$ & $\begin{array}{l}\text { Surgical } \\
\text { technique }\end{array}$ & $\begin{array}{l}\text { Maintenance } \\
\text { therapy }\end{array}$ \\
\hline
\end{tabular}




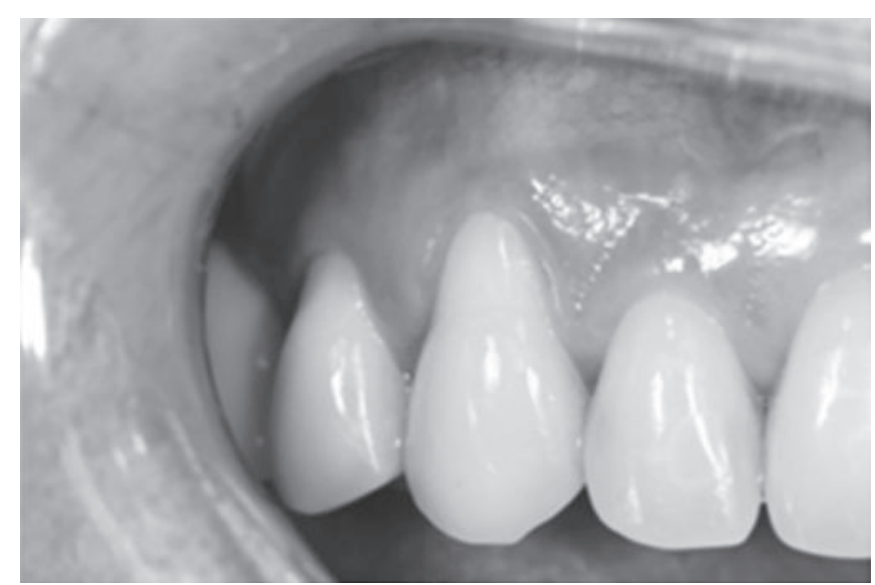

Fig. 1: Subepithelial connective tissue graft by the coronally positioned flap technique-initial (control group)

and without tension could be obtained. The subepithelial connective tissue grafts were placed on the proximal recession and stabilized in the proximal areas with a resorbable polyglycolic acid thread (BIOLINE, Anapolis, Goias, Brazil). After that, the flap was sutured on the graft with 6.0 nylon thread (SHALON San Luis M. Belos, Goias, Brazil) (Figs 1 and 2). In this technique, surgical cement (COE-PAK ${ }^{\mathrm{TM}}$, GC AMERICA, Alsip, Illinois, USA) was applied on the area. This technique was similar to that recommended by Langer and Langer. ${ }^{8}$

\section{Modified Envelope Technique}

This technique was started by obtaining the receptor area where the terminal infiltrative anesthesia was performed using the same anesthetic agent as used in the control group (Fig. 3). Intrasulcular incision without papillae involvement was made with $15 \mathrm{c}$ Solidor ${ }^{\circledR}$ blade (Suzhou Kyuan Medical Apparatus Co. Ltd., Suzhou City, Beiqiao Town, China). The envelope was created with a tunneler (Helmut Zepf Medizintechnik $\mathrm{GmbH}$, Seitingen-oberflacht, Germany) through a whole thickness detachment near the gingival

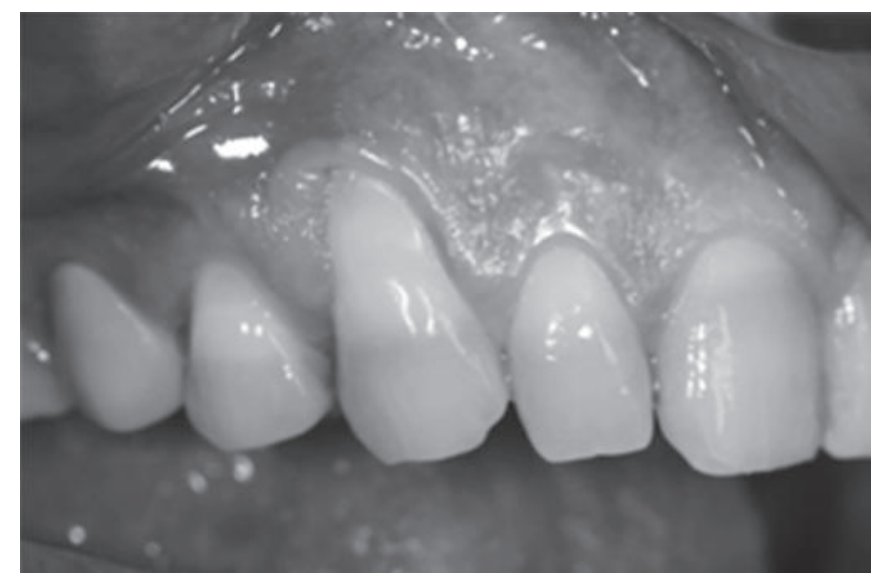

Fig. 3: Subepithelial connective tissue graft by the modified envelope technique-initial (test group)

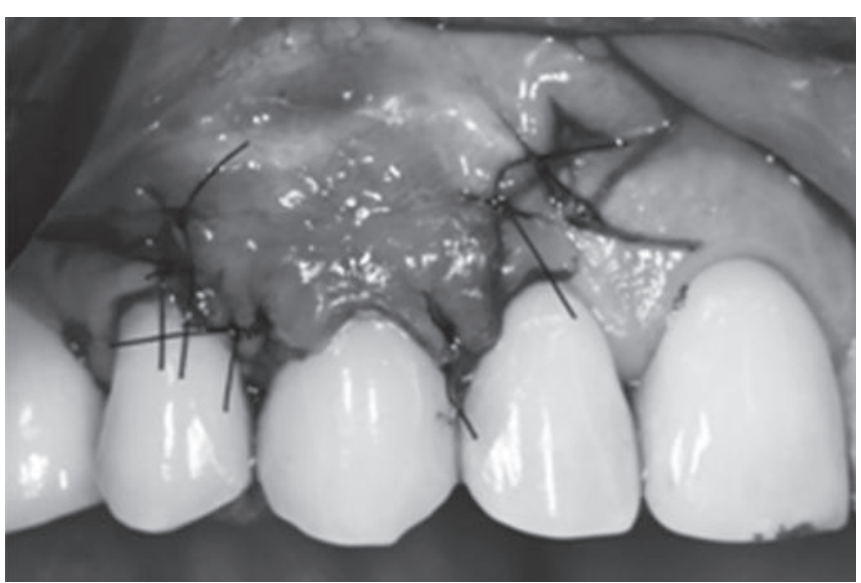

Fig. 2: Subepithelial connective tissue graft by the coronally positioned flap technique-after final suture (control group)

margin beyond the mucogingival junction, followed by a split "array"-shaped flap, overtaking the boundaries of the recession so that the flap was immobilized without tensions, to the CEJ (Figs 3 and 4). This technique was similar to that described by Allen. ${ }^{11}$

After preparation of the receiving area, the donor region selected for both techniques was the palatine region between canines and mesial of first molars, respecting the anatomical limits. After terminal infiltrative anesthesia, the graft tissue was obtained by the double incision technique described by Raetzke ${ }^{15}$; this area was sutured with 5.0 nylon thread (Shalon São Luis M. Belos, Goias, Brazil) (Fig. 4) and protected by continuous suture with surgical cement (COE-PAK ${ }^{\mathrm{TM}}$, GC AMERICA, Alsip, Illinois, USA).

\section{Statistical Analyses}

All data were analyzed and evaluated initially through Shapiro-Wilk tests for checking the normal distribution, and then analysis of variance and Tukey's tests were used. The only exception was the analysis of the sensitivity

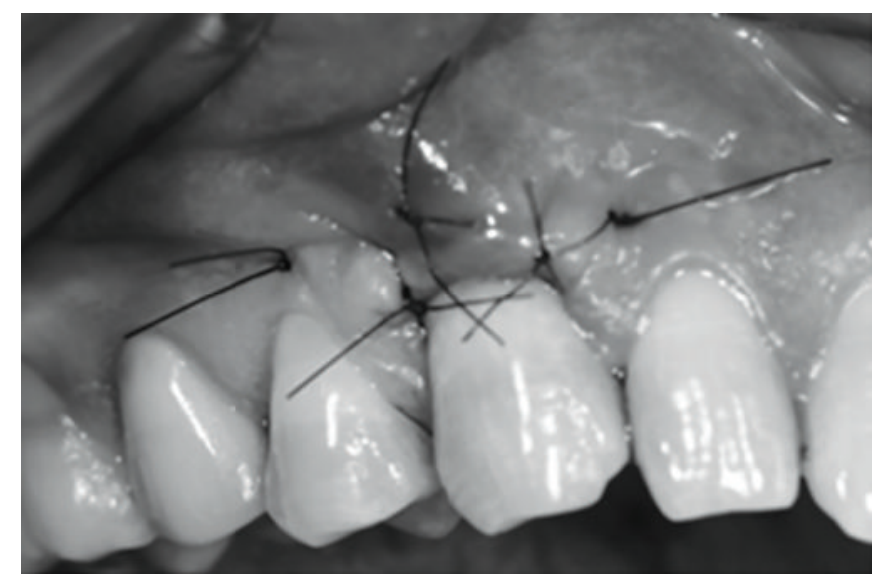

Fig. 4: Subepithelial connective tissue graft by the modified envelope technique-coverage of the subepithelial connective tissue graft with suspensor suture (test group) 
parameter where Kruskal-Wallis and Dunn tests were used, at 5\% significance. The BioEstat 5.4 software (Mamiraua Institute, Amazon, Brazil) was used to carry out all the statistical analyses.

\section{RESULTS}

In relation to probing depth, both techniques were effective. The periodontal health was maintained during the evaluation period, without significant change ( $p>0.05$; Table 2). There was a gain in clinical attachment level $(p<0.05)$ in both groups from 90 days after the surgeries, maintaining the gain at 180 days. They were most notable for the control group, which had a clinical attachment level gain still statistically significant after 180 days ( $<<0.05)$. These results were also shown when the results were compared between the groups at 180 days. The control group presented a statistically significant gain when compared with the test group $(p<0.05)$. There was a statistically significant gain $(p<0.05)$ in the height of keratinized tissue at 90 days for both groups (Figs 5 and 6), remaining stable up to 180 days. In other periods and parameters, there was no statistical difference between the groups in the same period $(p>0.05)$.

There was a statistically significant decrease $(\mathrm{p}<0.05)$ from the gingival recession level at 90 days for both groups, remaining stable up to 180 days (Table 3; Figs 5 and 6). Regarding the dental sensibility score, the two groups showed a significant reduction $(p<0.05)$ from 90 days after surgeries were performed maintaining this reduction during 180 days. There was no statistical difference between the groups in the same period $(p>0.05)$, whereas in relation to the plaque index, the two groups showed a significant reduction $(p<0.05)$ from 90 days after the surgeries, maintaining the reduction during 180 days. In gingival index, both groups showed a significant reduction $(\mathrm{p}<0.05)$ from 90 days after the surgeries, maintaining this reduction during 180 days. In comparison between groups in the same period, there was no statistical difference $(\mathrm{p}>0.05)$.

Regarding the percentage of root coverage, the control group showed a percentage of coverage of $90.2 \%$ and the test group of $89.5 \%$.

Table 2: Analysis of the periodontal parameters of the probing depth, attachment, and width of keratinized tissue in groups evaluated in 0,90 , and 180 days

\begin{tabular}{|c|c|c|c|c|c|c|c|c|}
\hline \multirow{3}{*}{$\begin{array}{l}\text { Periodontal } \\
\text { parameters }\end{array}$} & \multicolumn{8}{|c|}{ Groups } \\
\hline & \multicolumn{4}{|c|}{ Test } & \multicolumn{4}{|c|}{ Control } \\
\hline & Day 0 & 90 days & 180 days & $\Delta(0-180)$ & Day 0 & 90 days & 180 days & $\Delta(0-180)$ \\
\hline $\begin{array}{l}\text { Probing depth } \\
(\mathrm{mm})\end{array}$ & $1.73 \pm 0.59 \mathrm{~A}$ & $2.17 \pm 0.89 \mathrm{~A}$ & $1.85 \pm 0.77 \mathrm{~A}$ & $0.12 \pm 0.08$ & $1.56 \pm 0.49 \mathrm{~A}$ & $1.90 \pm 0.70 \mathrm{~A}$ & $1.77 \pm 0.75 \mathrm{~A}$ & $0.19 \pm 0.10^{*}$ \\
\hline $\begin{array}{l}\text { Clinical } \\
\text { attachment level } \\
(\mathrm{mm})\end{array}$ & $4.38 \pm 0.86 \mathrm{~A}$ & $2.50 \pm 0.67 \mathrm{~B}$ & $2.38 \pm 0.86 \mathrm{~B}$ & $2.00 \pm 0.34$ & $4.15 \pm 0.89 A$ & $2.84 \pm 1.34 \mathrm{~B}$ & $1.71 \pm 0.75 \mathrm{C}$ & $2.44 \pm 0.38^{*}$ \\
\hline $\begin{array}{l}\text { Height } \\
\text { keratinized } \\
\text { tissue }(\mathrm{mm})\end{array}$ & $1.41 \pm 0.50 \mathrm{~A}$ & $2.11 \pm 0.92 B$ & $2.80 \pm 0.67 \mathrm{C}$ & $1.39 \pm 0.54$ & $1.50 \pm 0.51 \mathrm{~A}$ & $2.27 \pm 0.89 B$ & $2.76 \pm 0.41 \mathrm{C}$ & $1.26 \pm 0.51$ \\
\hline
\end{tabular}

Different letters signify statistically significant difference between means within each treatment group at $p<0.05$. The values represent mean \pm standard deviation. *Statistically significant difference between the variation of the means $(\Delta)$, considering the two treatment groups at $p<0.05$

Table 3: Analysis of the periodontal parameters of the gingival level (recession) and dental sensibility in groups evaluated in 0,90 , and 180 days

\begin{tabular}{|c|c|c|c|c|c|c|c|c|}
\hline \multirow{3}{*}{$\begin{array}{l}\text { Periodontal } \\
\text { parameters }\end{array}$} & \multicolumn{8}{|c|}{ Groups } \\
\hline & \multicolumn{4}{|c|}{ Test } & \multicolumn{4}{|c|}{ Control } \\
\hline & Day 0 & 90 days & 180 days & $\Delta(0-180)$ & Day 0 & 90 days & 180 days & $\Delta(0-180)$ \\
\hline $\begin{array}{l}\text { Plaque index } \\
\text { (percentages) }\end{array}$ & $10.28 \pm 17.54 \mathrm{~A}$ & $2.92 \pm 5.82 \mathrm{~B}$ & $1.47 \pm 3.27 \mathrm{C}$ & $8.81 \pm 1.24$ & $9.78 \pm 20.65 \mathrm{~A}$ & $1.95 \pm 5.51 \mathrm{~B}$ & $1.95 \pm 4.67 \mathrm{~B}$ & $7.83 \pm 1.47^{\star}$ \\
\hline $\begin{array}{l}\text { Gingival index } \\
\text { (percentages) }\end{array}$ & $4.41 \pm 4.40 \mathrm{~A}$ & $0.98 \pm 0.97 \mathrm{~B}$ & $0 \pm 0 \mathrm{C}$ & $4.41 \pm 4.41$ & $4.88 \pm 4.87 \mathrm{~A}$ & $0.49 \pm 0.48 \mathrm{~B}$ & $0 \pm 0 \mathrm{C}$ & $4.88 \pm 4.87$ \\
\hline $\begin{array}{l}\text { Gingival level } \\
\text { (recession) } \\
(\mathrm{mm})\end{array}$ & $2.76 \pm 0.90 \mathrm{~A}$ & $0.35 \pm 0.60 \mathrm{~B}$ & $0.29 \pm 0.58 \mathrm{~B}$ & $2.47 \pm 0.53$ & $2.94 \pm 1.08 \mathrm{~A}$ & $0.52 \pm 0.71 \mathrm{~B}$ & $0.29 \pm 0.46 \mathrm{~B}$ & $2.65 \pm 0.54$ \\
\hline $\begin{array}{l}\text { Dental } \\
\text { sensibility } \\
\text { (scores) }\end{array}$ & $2.11(0.92) A$ & $0.82(1.01) \mathrm{B}$ & 0.70 (0.98)B & - & $2.11(0.69) A$ & $0.35(0.78) \mathrm{B}$ & 0.35 (0.78)B & - \\
\hline
\end{tabular}

Different letters signify statistically significant difference between means within each treatment group at $p<0.05$. The values represent mean \pm standard deviation. *Statistically significant difference between the variation of the means $(\Delta)$, considering the two treatment groups at $\mathrm{p}<0.05$ 


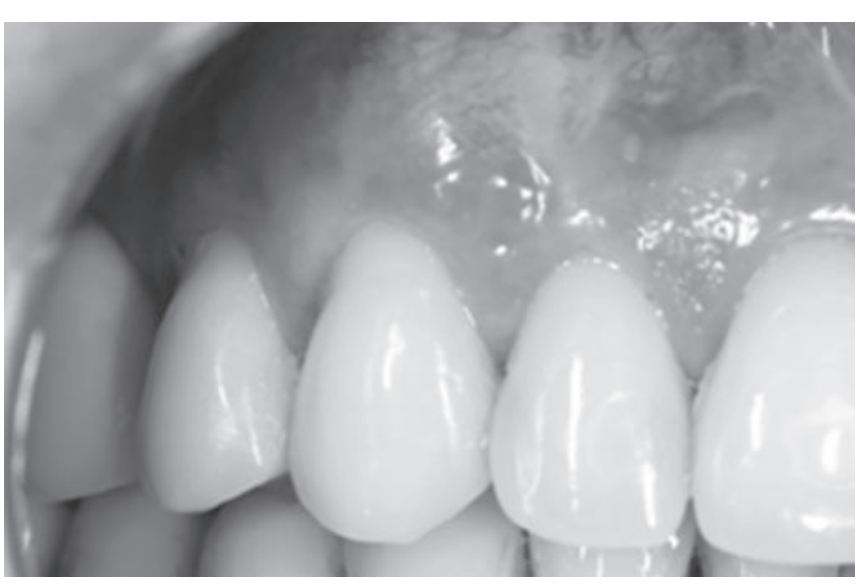

Fig. 5: Subepithelial connective tissue graft by the coronally positioned flap technique-postoperative monitoring 180 days (control group)

\section{DISCUSSION}

The procedures of mucogingival plastic surgery and gingival recession covering are challenges encountered daily in our clinical practice, and many local anatomical conditions can influence the treatment and prognosis of recessions. Among these conditions, the presence alveolar bone interproximal, gingival thickness, amount of keratinized tissue, the presence of cervical lesions, the size of adjacent papillae, and the location of the tooth, ${ }^{19}$ including the skills and experience of the surgeon, have already been emphasized by Cortellini et $\mathrm{al}^{20}$ and Tonetti and Jepsen. ${ }^{21}$ Other factors that can limit root coverage are related to the correct identification of anatomical CEJ, the presence of cervical abrasions associated with recession, rotations and extrusions, ${ }^{22}$ as well as loss of height, even with no interproximal bone loss. ${ }^{23}$

Patients with gingival recession who present with complaints related to esthetics and root hypersensitivity are candidates for mucogingival root coverage therapies. Obtaining root coverage in areas with localized or generalized loss of periodontal tissue is one of the therapeutic goals of mucogingival surgery. ${ }^{15}$ Hence, the aim of this study was to evaluate the effectiveness of two different techniques of subepithelial connective tissue graft, the modified envelope technique ${ }^{10}$ and the displaced coronary technique, ${ }^{8}$ both associated with a subepithelial connective tissue graft for coverage of gingival recession, in Miller classes I and II for 180 days.

Several studies have shown great results when using the method of Langer and Langer ${ }^{8}$ for root coverage; among them, there are the methods by Paolantonio et $\mathrm{al}^{24}$ $(90 \%)$ and Tözüm et al ${ }^{25}(75.5 \%)$. The result of this study is close to these percentages of coverage, with $90.2 \%$ of root coverage reached in 180 days. The use of vertical relaxing incisions described in the article provides for obtaining a flap without tension, which can be mobilized

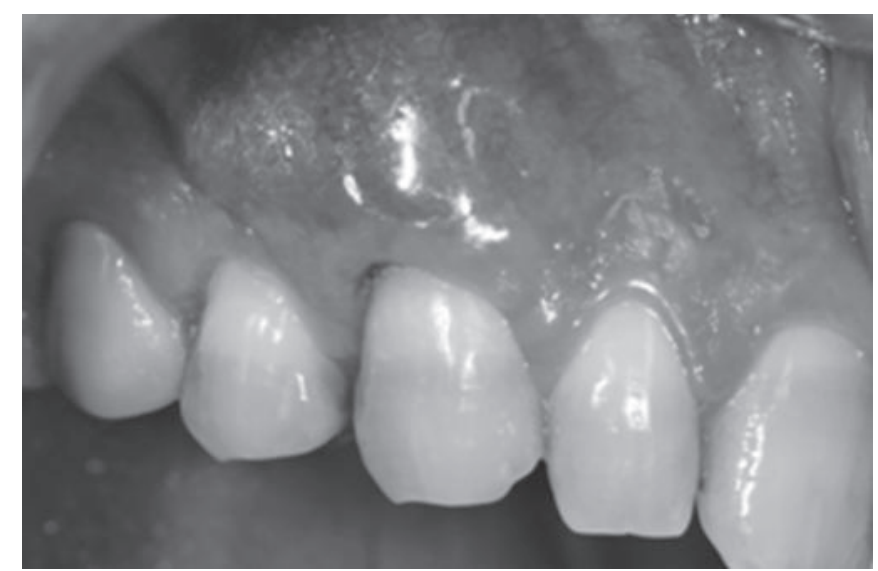

Fig. 6: Subepithelial connective tissue graft by the modified envelope technique-postoperative monitoring 180 days (test group)

in coronal position to the CEJ. In another study, Pini Prato et $\mathrm{al}^{26}$ stated that if the gingival margin is sutured to $2 \mathrm{~mm}$ or more, coronal to the CEJ, one can already get the full coverage of gingival recession, resulting in good rates reported in the literature, both for single and multiple recessions, as described by Langer and Langer ${ }^{8}$ and Santarelli et al. ${ }^{27}$ However, due to the realization of vertical incisions there is reduced local blood supply and the occurrence of unwanted scarring. ${ }^{28}$

In the surgery with the modified envelope technique, ${ }^{11}$ there is $84 \%$ of root coverage in this study by this author, but in other studies, Tözüm and Dini ${ }^{29}$ showed $95 \%$ and Tözüm et $\mathrm{al}^{25}$ showed $96.4 \%$ of root coverage, but in this study, we obtained $89.5 \%$ of root coverage.

The authors cited earlier claim that the use of this technique preserves the interdental papillae, minimizing the possibility of scarring, providing a better blood supply, and may accelerate the initial healing, ${ }^{30}$ and therefore, the results of our study are similar to the results demonstrated in the literature.

Both techniques have shown to be highly predictable for the proposed procedure (Figs 5 and 6); there was a significant reduction for the clinical attachment level at 90 days for both groups, but the control group had an additional gain at 180 days (Table 2), probably one of the associated factors may be the lower tension and positioning of flap proposed in the test group. ${ }^{31} \mathrm{In}$ other periodontal parameters examined, all showed a significant reduction of the initial period for 180 days, demonstrating the effectiveness of the two techniques (Tables 2 and 3).

According to literature, after 5 months of root coverage surgery by the techniques used in this study, some regeneration level in periodontal defects with new cement, ${ }^{32,33}$ bone formation, ${ }^{32,33}$ and periodontal ligament ${ }^{9}$ as well as large portions of the root covered by connective tissue 
and long junctional epithelium was found. ${ }^{32-34}$ Since probably periodontal ligament cells in the side portions of the defect act as a stimulator of granulation tissue, a new insertion could develop. ${ }^{15,26,35}$

All patients participated in the maintenance care throughout the study and were monitored based on their brushing technique and were also included in maintenance programs until the end of this research. The improvement of periodontal parameters over 180 days was taken as results of maintenance. The results demonstrated that monitoring and maintenance of the proposed periodontal treatments may present significant improvements in these indexes, as shown in a long-term observation by Pini Prato et al. ${ }^{26}$

\section{CONCLUSION}

Within the limitations of this study and based on the results, it was concluded that after 180 days both the techniques were effective for the health of periodontal tissues and root coverage of patients with gingival recession Miller classes I and II; however, a greater emphasis can be observed on the subepithelial connective tissue graft associated with coronally positioned flap technique because this technique demonstrated a greater significant gain in the clinical attachment level.

\section{ACKNOWLEDGMENTS}

This study was supported by the Foundation for PostGraduate Education (CAPES), Brasilia, Brazil, and West of Parana State University, Cascavel, Paraná, Brazil.

\section{REFERENCES}

1. American Academy of Periodontology (AAP). Glossary of periodontal terms. J Periodontol 2001, 4th Edition, p. 44. (most current).

2. Bignozzi I, Littarru C, Crea A, Orgeas GV, Landi L. Surgical treatment options for grafting areas of gingival recession association with cervical lesions: a review. J Esthet Restor Dent 2013 Dec;25(6):371-382.

3. Zucchelli G, Mounssif I. Periodontal plastic surgery. Periodontol 20002015 Jun;68(1):333-368.

4. Bernimoulin JP, Lüscher B, Mühlemann HR. Coronally repositioned periodontal flap. Clinical evaluation after one year. J Clin Periodontol 1975 Feb;2(1):1-13.

5. Liu WJ, Solt CW. A surgical procedure for the treatment of localized gingival recession in conjunction with root surface citric acid conditioning. J Periodontol 1980 Sep;51(9): 505-509.

6. Cairo F, Pagliaro U, Nieri M. Treatment of gingival recession with coronally advanced flap procedures: a systematic review. J Clin Periodontol 2008 Sep;35(8 Suppl):136-162.

7. Cairo F, Rotundo R, Miller PD, Pini Prato GP. Root coverage esthetic score: a system to evaluate the esthetic outcome of the treatment of gingival recession through evaluation of clinical cases. J Periodontol 2009 Apr;80(4):705-710.
8. Langer B, Langer L. Subepithelial connective tissue graft technique for root coverage. J Periodontol 1985 Dec;56(12):715-720.

9. Zucchelli G, Marzadori M, Mounssif I, Mazzotti C, Stefanini M. Coronally advanced flap connective tissue graft techniques for the treatment of deep gingival recession in the lower incisors. A controlled randomized clinical trial. J Clin Periodontol 2014 Aug;41(8):806-813.

10. Raetzke PB. Covering localized areas of root exposure employing the "envelope" technique. J Periodontol 1985 Jul;56(7):397-402.

11. Allen A. Use of the supraperiosteal envelope in soft tissue grafting for root coverage. I. Rationale and technique. Int J Periodontics Restorative Dent 1994 Jun;14(3):216-227.

12. Miller PD Jr. A classification of marginal tissue recession. Int J Periodontics Restorative Dent 1985;5(2):8-13.

13. Pihlstrom BL, Curran AE, Voelker HT, Kingman A. Randomized controlled trials: what are they and who needs them? Periodontol 20002012 Jun;59(1):14-31.

14. Chambrone L, Sukekava F, Araújo MG, Pustiglioni FE, Chambrone LA, Lima LA. Root-coverage procedures for the treatment of localized recession-type defects: a Cochrane systematic review. J Periodontol 2010 Apr;81(4):452-478.

15. Nassar CA, da Silva WA, Tonet K, Secundes MB, Nassar PO. Comparing semilunar coronally positioned flap to standard coronally positioned flap using periodontal clinical parameters. Gen Dent 2014 Mar-Apr;62(2):47-49.

16. Silness J, Löe H. Periodontal disease in pregnancy. II - correlation between oral hygiene and periodontol condition. Acta Odontol Scand 1964 Feb;22:121-135.

17. Loe H, Silness J. Periodontal disease in pregnancy. I. Prevalence and severity. Acta Odontol Scand 1963 Dec;21:533-551.

18. Bayne SC, Schmalz G. Reprinting the classic article on USPHS evaluation methods for measuring the clinical research performance of restorative materials. Clin Oral Investig 2005 Dec;9(4):209-214.

19. de Sanctis M, Clementini M. Flap approaches in plastic periodontal and implant surgery: critical elements in design and execution. J Clin Periodontol 2014 Apr;41 (Suppl 15):S108-S122.

20. Cortellini P, Tonetti M, Baldi C, Francetti L, Rasperini G, Rotundo R, Nieri M, Franceschi D, Labriola A, Prato GP. Does placement of a connective tissue graft improve the outcomes of coronally advanced flap for coverage of single gingival recessions in upper anterior teeth? A multi-centre, randomized, double-blind, clinical trial. J Clin Periodontol 2009 Jan;36(1):68-79.

21. Tonetti MS, Jepsen S, Working Group of the European Workshop on Periodontology. Clinical efficacy of periodontal plastic surgery procedures: consensus report of Group 2 of the 10th European Workshop on Periodontology. J Clin Periodontol 2014 Apr;41 (Suppl 15):S36-S43.

22. Zucchelli G, Testori T, De Sanctis M. Clinical and anatomical factors limiting treatment outcomes of gingival recession: a new method to predetermine the line of root coverage. J Periodontol 2006 Apr;77(4):714-721.

23. Prato GP, Rotundo R, Cortellini P, Tinti C, Azzi R. Interdental papilla management: a review and classification of the therapeutic approaches. Int J Periodontics Restorative Dent 2004 Jun;24(3):246-255.

24. Paolantonio M, di Murro C, Cattabriga A, Cattabriga M. Subpedicle connective tissue graft versus free gingival graft in the coverage of exposed root surfaces. A 5-year clinical study. J Clin Periodontol 1997 Jan;24(1):51-56. 
25. Tözüm TF, Keçeli HG, Güncü GN, Hatipoglu H, Sengün D. Treatment of gingival recession: comparison of two techniques of subepithelial connective tissue graft. J Periodontol 2005 Nov;76(11):1842-1848.

26. Pini Prato GP, Baldi C, Nieri M, Franseschi D, Cortellini P, Clauser C, Rotundo R, Muzzi L. Coronally advanced flap: the post-surgical position of the gingival margin is an important factor for achieving complete root coverage. J Periodontol 2005 May;76(5):713-722.

27. Santarelli GA, Ciancaglini R, Campanari F, Dinoi C, Ferraris $\mathrm{S}$. Connective tissue grafting employing the tunnel technique: a case report of complete root coverage in the anterior maxilla. Int J Periodontics Restorative Dent 2001 Feb;21(1):77-83.

28. ZucchelliG,MeleM,MazzottiC,MarzadoriM,MontebugnoliL, De Sanctis M. Coronally advanced flap with and without vertical releasing incisions for the treatment of multiple gingival recessions: a comparative controlled randomized clinical trial. J Periodontol 2009 Jul;80(7):1083-1094.

29. Tözüm TF, Dini FM. Treatment of adjacent gingival recessions with subepithelial connective tissue grafts and the modified tunnel technique. Quintessence Int 2003 Jan;34(1):7-13.
30. Mörmann W, Meier C, Firestone A. Gingival blood circulation after experimental wounds in man. J Clin Periodontol 1979 Dec;6(6):417-424.

31. Huang H, Neiva RE, Wang HL. Factors affecting histology of a human biopsy section following the placement of a subepithelial connective tissue graft. Int J Periodontics Restorative Dent 2000 Jun;20(3):225-231.

32. Bruno JF, Bowers GM. Histology of a human biopsy section following the placement of a subepithelial connective tissue graft. Int J Periodontics Restorative Dent 2000 Jun;20(3): 225-231.

33. Majzoub Z, Landi L, Grusovin MG, Cordioli G. Histology of connective tissue graft. A case report. J Periodontol 2001 Nov;72(11):1607-1615.

34. McGuire MK, Cochran DL. Evaluation of human recession defects treated with coronally advanced flaps and either enamel matrix derivative or connective tissue. Part 2: Histological evaluation. J Periodontol 2003 Aug;74(8):1126-1135.

35. Bittencourt S, Ribeiro Edel P, Sallum EA, Sallum AW, Nociti FH Jr, Casati MZ. Root surface biomodification with EDTA for the treatment of gingival recession with a semilunar coronally repositioned flap. J Periodontol 2007 Sep;78(9):1695-1701. 